\title{
Antibacterial and antioxidant activity of some seeds used as food
}

\author{
Kenan Tunç ${ }^{\mathbb{D}}$, Alican Bahadır Semerci ${ }^{\circledR}$, Esin Çınar ${ }^{\circledR}$
}

Cite this article as:

Tunç, K., Semerci, A.B., Çınar, E. (2020). ANtibacterial and antioxidant activity of some seeds used as food. Food and Health, 6(4), $261-266$. https://doi.org/10.3153/FH20026

Sakarya University, Arts and Science Faculty, Department of Biology, 54087 Serdivan, Sakarya, Turkey

\section{ORCID IDs of the authors:}

K.T. 0000-0002-9888-1453

A.B.S. 0000-0001-9502-9321

E.Ç. 0000-0002-2141-5251

Submitted: 22.02 .2020

Revision requested: 16.05 .2020

Last revision received: 22.05 .2020

Accepted: 01.06.2020

Published online: 28.08 .2020

Correspondence: Kenan TUNÇ

E-mail: ktunc@sakarya.edu.tr

\begin{abstract}
In this study, antioxidant and antibacterial activities of Brassica nigra, Linum usitatissimum, Salvia hispanica, Nigella sativa, Chenopodium quinoa seeds prepared with ethanol were determined. Antioxidant capacity has been measure by evaluating DPPH radical scavenging activity level and antibacterial activities were investigated by using the disc diffusion method. Highest antibacterial activity level has been detected for the seed of $N$. sativa. As a result of this study there exist no any antibacterial effect in the seeds of B. nigra and L. usitatissimum. The extract of $N$. sativa seed has shown an inhibition zone of $14.5 \mathrm{~mm}$ on Staphylococcus aureus, whereas this value has been detected to be $10.5 \mathrm{~mm}$ for both on the seeds of Enterococcus faecalis and Staphylococcus epidermidis. $\mathrm{IC}_{50}$ value showing the $50 \%$ scavenging value of DPPH radical has been determined to be $51 \mu \mathrm{g} / \mathrm{mL}$ for the seed extrafct of $B$. nigra as the highest one between the all seed samples searched. All seeds used in the current study which are known to be functional food have shown certain level of antioxidant activity.
\end{abstract}

Keywords: Antioxidant, Antibacterial, Seed

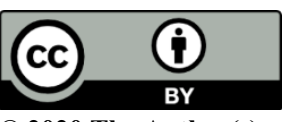

(C) 2020 The Author(s)

Available online at

http://jfhs.scientificwebjournals.com 


\section{Introduction}

Today, about 40000 plant species are known, some of which are collected from the nature, while others are cultured and produced. A significant part of the plants used for health treatments are collected from the nature and these plants are named as medicinal plants. It is well known for the medicinal plants that they have been used for many similar purposes such as food, medicine, cosmetics and spices since the beginning of human history (Acıbuca and Bostan Budak, 2018; Semerci et. al., 2020).

Medicinal plants and some spices contain highly useful phytochemical and antioxidant properties due to various chemicals contained in them (Virendra et. al., 2013). Mustard with antioxidant properties makes the skin look brighter and more vivid. The oil created from the seed is used to relieve the pain in the various parts of the human body. The oil obtained from mustard seeds cannot be used for nutritional purposes due to its fatty acids, especially due to its high amount of erucic acid, but it can be used for different purposes in the pharmaceutical and cosmetic industries (G1d1k, 2016).

L. usitatissimum is often called "functional food", "bioactive food" and "endocrine active food" and its nutrient value together with its protective properties originate from its distinct ingredients (İşleroğlu et.al., 2005). Flax or flax seed are among the oldest crops grown for oil and fiber (Jhala and Hall, 2010). Flax plant contains essential fatty acids, omega3 and 6 fatty acids, linoleic acid, alpha linolenic acid (ALA) necessary for health protection. It is also known as a good source of antioxidants (Üstü and Keskin, 2019).

S. hispanica is classified as functional food due to essential nutrients in its structure. It has a protective effect against cardiovascular diseases, nervous system disorders, inflammatory and diabetes (Ergene and Bingöl, 2019). As a natural source of chia seeds n-3 fatty acids, it is effective in lowering blood triglycerides and regulating blood cholesterol levels thanks to its $\beta$-sterol content.

$N$. sativa has properties such as repairing cell damages that may occur in the human body. It has also immune stimulating, anti-inflammatory, anticancer, antioxidant, antiastmatic, hypoglycemic, antimicrobial and antiparasitic characteristics (Al Ali et.al., 2008).

C. quinoa seeds are rich in nutrients. It is a good source of minerals such as protein, calcium, iron and vitamins $\mathrm{E}$ and $\mathrm{B}$. All 8 essential amino acids necessary for tissue development in humans are found in the seed of this plant (Tan and Yöndem, 2013).
In this study, it is aimed to clarify the antibacterial and antioxidant activities of B. nigra, L. usitatissimum, S. hispanica, $N$. sativa, $C$. quinoa seeds.

\section{Materials and Methods}

Seeds of B. nigra L., L. usitatissimum L., S. hispanica L., $N$. sativa L., $C$. quinoa Wild. used in the research were taken from the herbalist in Sakarya province. Plant seeds taken from the herbalist were crushed in an electric grinder and powdered.

\section{Preparation of Herbal Extracts}

Extracts were prepared by weighing the ground seed samples to $10 \mathrm{~g}$ and adding them separately into $100 \mathrm{~mL}$ ethanol (Tunç et.al., 2019). These prepared extracts are kept in a cool and dark environment for 3 days and mixed in a magnetic mixer at regular intervals. Extracts were prepared according to the maceration method. At the end of the process, the extracts were filtered through filter paper and the solvents in the extract were removed with a rotary evaporator. After these processes, the extracts were prepared at the determined concentration $(6400 \mu \mathrm{g} / \mathrm{disc})$ by adding solvents that used in the extraction process. Of the raw extracts obtained, empty sterile discs with the radius of $6 \mathrm{~mm}$ were absorbed $10 \mu \mathrm{L}$ and kept in a dark sterile environment for 24 hours.

\section{Supply of Bacterial Strains}

The microorganisms used in the study were obtained from the strain collection of Sakarya University, Faculty of Arts and Sciences, Department of Biology, Microbiology Research Laboratory. Bacillus subtilis ATCC 6633, Escherichia coli ATCC 8739, E. faecalis ATCC 29212, S. aureus ATCC 29213 and S. epidermidis ATCC 12228 bacteria were used in the study.

\section{Disc Diffusion Method}

Antibacterial activity of extracts was determined using the disc diffusion method. The concentration of the previously activated strains was adjusted to an average of $0.5 \mathrm{McF}$ arland overnight and Müeller Hinton Agar was cultivated with a sterile swab. Extracts impregnated discs with the pliers were placed in Müeller Hinton Agar in aseptic conditions where bacteria were cultivated. They were incubated at $37^{\circ} \mathrm{C}$ for 24 hours. If there is an inhibition zone against that pathogen around the disc as a result of the incubation, the zone diameters $(\mathrm{mm})$ have been measured from the back of the petri by using a digital caliper.

All studies were carried out in triplicate. Gentamicin was used as the positive control and ethanol as the negative one. 


\section{Determination of Antioxidant Activity}

For example, antioxidant activity was investigated by modified DPPH free radical scavenging method (Blois, 1958). After taking $1 \mathrm{~mL}$ of standart solution and ectracts prepared in various concentrations we have added a DPPH solution of 1 $\mathrm{mL}$ with $0.04 \%$ concentration. After vortexing, they were left in a dark place for 30 mins and their absorbance have been measere at $517 \mathrm{~nm}$. The results have been attained by evaluating the $\mathrm{DPPH} \%$ radical scavenging activity and $\mathrm{IC}_{50}$ value. During the experiments DPPH and ethanol together with ascorbic acid as standart have been used:

DPPH $\%$ scavenging activity $=100 \times$ (Absorbance of controlAborbance of sample)/Absorbance of control

The regression value of the extracts prepared at different concentrations was calculated with the results obtained from the $\%$ DPPH scavennging activity. $\mathrm{IC}_{50}$ ratios were determined from this equation.

\section{Results and Discussion}

To our knowledge this is the first study demonstrating both the antibacterial and antioxidant activities at the same time for five functional foods, namely B. nigra, L. usitatissimum, S. hispanica, N. Sativa, C. quinoa.

Inhibition zone diameter measurements of extracts prepared from B. nigra, L. usitatissimum, S. hispanica, N. Sativa, $C$. quinoa plants against test microorganisms are given in Table 1.

While B. nigra and L. usitatissimum seed extracts do not form inhibition zone diameters, $S$. hispanica seed extract has been determined to form an $8 \mathrm{~mm}$ inhibition zone diameter on $S$. epidermidis and $9 \mathrm{~mm}$ on $S$. aureus.

$N$. sativa seed extract has shown an inhibition zone diameter of $10.5 \mathrm{~mm}$ on E. faecalis and S. epidermidis, and $14.5 \mathrm{~mm}$ on $S$. aureus. C. quinoa seed extract produced $9.25 \mathrm{~mm}$ inhibition zone diameter only on $S$. aureus.

In a study, it was reported that black seed extract prepared with diethylether was observed on gram positive bacteria $(S$. aureus) while there was no antibacterial activity on gram negative bacteria (E. coli) (Mohammed and Mohammed, 2000).

Gerige et. al. (2009) examined the antimicrobial activity of the oils obtained from the seeds of black seed and determined that this oil formed a $18 \mathrm{~mm} \mathrm{~B}$. subtilis $10 \mathrm{~mm}$ inhibition zone diameter on $S$. aureus.

In this study, while $N$. sativa seed extract was determined to have $14.5 \mathrm{~mm}$ inhibition zone diameter on $S$. aureus, no antibacterial activity was observed on B. subtilis. This is thought to be due to differences in extract preparation methods or differences in growing site.

In the $S$. hispanica study, many bacteria were studied and the effect of Chia seed on them was investigated.

Table 1. Inhibition zone diameters of seed extracts on test bacteria

\begin{tabular}{llllll}
\hline Plant extracts & \multicolumn{5}{c}{ TEST MICROORGANISMS } \\
\cline { 2 - 6 }$(6400 \mu \mathrm{g} / \mathrm{disc})$ & E. coli & B. subtilis & E. faecalis & S.epidermidis & S. aureus \\
\hline B. nigra & 0 & 0 & 0 & 0 & 0 \\
L. usitatissimum & 0 & 0 & 0 & 0 & 0 \\
S. hispanica & 0 & 0 & 0 & $8 \pm 0$ & $9 \pm 0$ \\
N. sativa & 0 & 0 & $10.5 \pm 0.7$ & $10.5 \pm 0.7$ & $14.5 \pm 3.3$ \\
C. quinoa & 0 & 0 & 0 & 0 & $9.25 \pm 0.3$ \\
Gentamicin & 19 & 17 & 20 & 21 & 20 \\
\hline
\end{tabular}




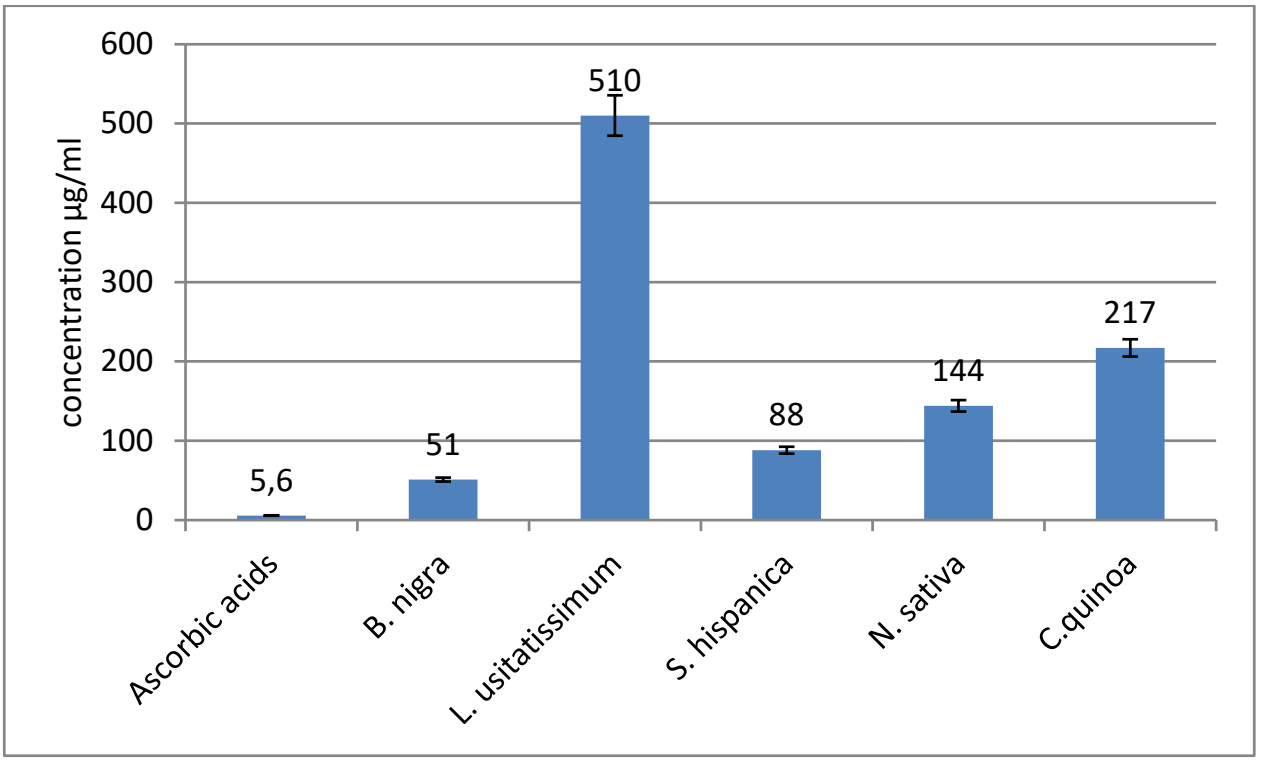

Figure 1. $\mathrm{IC}_{50}$ values measured for the seed extracts and ascorbic acid.

Thus, the ability to scavenge free radicals is an important antioxidant property in minimizing oxidative cellular damage. In a series of in vitro tests the essential oils from spices and medicinal plants have exhibited remarkable antioxidant activity (El-Baroty et al., 2010).

$\mathrm{IC}_{50}$ value is expressed as the amount of exract inhibiting the radical concentration to a degree of $50 \%$. The lower value of $\mathrm{IC}_{50}$ shows that the antioxidant level of the plant is higher. The highest DPPH antioxidant activity level for the current study has been measured for the B. nigra seed extract, whereas the lowest one detected for the $L$. usitatissimum seed extract. $\mathrm{IC}_{50}$ values for the seed extract are shown in Figure 1.

In a work done on the seed of $N$. sativa collected from the Koycegiz (Muğla), its seed oil constituents and anitoxidant activity level have been evaluated and $\mathrm{IC}_{50}$ value has been detected to be $52.61 \mu \mathrm{g} / \mathrm{mL}$ using scavenging activity of DPPH radical (Sicak and Erdoğan, 2019).

In another work done for the comparison of the antioxidant and antimicrobial activities of C. quinoa seed grown in Korea, America and Peru, it has been found that the $\mathrm{IC}_{50}$ values determined by using the DPPH radical scavenging activity was $250 \mu \mathrm{g} / \mathrm{mL}$ in Korea, whereas it was detected to be 260 $\mu \mathrm{g} / \mathrm{mL}$ and $470 \mu \mathrm{g} / \mathrm{mL}$ in America and Peru, respectively (Park et.al., 2017). The results of the current study are in good accordance with that study, even though the results may show slight changes owing to the collection area of the samples.

$\mathrm{IC}_{50}$ value of DPPH radical scavenging activity for the seed of $B$. nigra has been detected to be $63.09 \mu \mathrm{g} / \mathrm{mL}$ (Alam et.al.,
2011). B. nigra seed extract prepared with ethanol has shown $\mathrm{IC}_{50}$ value of $71.59 \mu \mathrm{g} / \mathrm{mL}$ in work done by (Krishnan-Radha et.al., 2015). In the current study we have measured $\mathrm{IC}_{50}$ value to be $51 \mu \mathrm{g} / \mathrm{mL}$, which are found to be compare well with the other work done by several researchers.

Anwar and Przybylski have studied the antioxidant activity of L. usitatissimum and found that for the extracts prepared in different solvent and concentration levels there existed some differences in the activity level. For instance, for the $100 \%$ methanol concentration level it has been detected to be 83.6, whereas it is 81.3 for $80 \%$ for the methanol and $42.2,100 \%$ for the ethanol concentrations $\mathrm{The}_{50} \mathrm{IC}_{50}$ value for L. usitatissimum has been obtained to be $510 \mu \mathrm{g} / \mathrm{mL}$ for the current study.

\section{Conclusions}

As a result, the highest microbial activity prepared out of $B$. nigra, L. usitatissimum, $S$. hispanica, $N$. sativa, $C$. quinoa seed extracts has been found in N. sativa. Antibacterial activity level order is as follows $N$. sativa, $S$. hispanica, $C$. quinoa. The highest antioxidant activity level has been detected for the seed of $B$. nigra. The antioxidant activity level order is as follows: B. nigra, S. hispanica, N. Sativa, C. quinoa, L. usitatissimum. 
Compliance with Ethical Standard

Conflict of interests: The authors declare that for this article they have no actual, potential or perceived the conflict of interests.

Ethics committee approval: Author declare that this study does not include any experiments with human or animal subjects.

Funding disclosure: -

Acknowledgments: -

Disclosure: -

\section{References}

Acıbuca, V., Bostan Budak, D. (2018). Dünya'da ve Türkiye'de tıbbi ve aromatik bitkilerin yeri ve önemi. Çukurova Tarım Gida Bilim Dergisi, 33(1), 37-44.

Al-Ali, A., Alkhawajah, A.A., Randhawa, M.A., Shaikh, N.A. (2008). Oral and intraperitoneal $\mathrm{LD}_{50}$ of thymoquinone, an active principle of Nigella sativa, in mice and rats. Journal of Ayub Medical College Abbottabad, 20(2), 252-257.

Alam, M.B., Hossain, M.S., Haque M.E. (2011). Antioxidant and anti-inflammatory activities of the leaf extract of Brassica nigra. International Journal of Pharmaceutical Sciences and Research, 2(2), 303-310.

Anwar, F., Przybylski, R. (2012). Effect of solvents extraction on total phenolics and antioxidant activity of extracts from flaxseed (Lınum usitatıssimum L.) Acta Scientiarum Polonorum Technologia Alimentaria, 11(3), 293-301.

Blois, M.S. (1958). Antioxidant determinations by the use of a stable free radical. Nature, 181, 1199-1200.

https://doi.org/10.1038/1811199a0.

El-Baroty, G.S., Abd El-Baky, H.H., Farag, R.S., Saleh M.A. (2010). Characterization of antioxidant and antimicrobial compounds of cinnamon and ginger essential oils. African Journal of Biochemistry Research, 4(6), 167-174.

Ergene, E., Bingöl, E.B. (2019). Diyet lif içeriği yüksek bazı g1dalar ve beslenme üzerindeki etkileri. Adnan Menderes Üniversitesi Sağlık Bilimleri Fakültesi Dergisi, 3(1), 70-78.

Gerige, S.J., Gerige Yadav, M.K., Rao, M. (2009). GC-MS analysis of Nigella sativa seeds and antimicrobial activity of it is volatile oil. Brazilian Archives of Biology and Technology, 52(5), 1678-4324.

https://doi.org/10.1590/S1516-89132009000500016
Gıdık, B. (2016). "Trakya bölgesi florası yabani hardal (Sinapis sp.) genotiplerinin moleküler ve morfolojik karakterizasyonu, tarla koşullarındaki verimi ile kalite unsurlarının değerlendirilmesi”, Doktara Tezi, Tez Danışman: Önemli, F., Namık Kemal Üniversitesi.

İşleroğlu, H., Yıldırım, Z., Yıldırım, M. (2005). Fonksiyonel bir gida olarak keten tohumu. Gaziosmanpaşa Üniversitesi Ziraat Fakültesi Dergisi, 22(2), 23-30.

Jhala, A., Hall, L. (2010). Flax (Linum usitatissimum L.): Current uses and future applications. Australian Journal of Basic and Applied Sciences, 4304-4312.

Krishnan Radha, K., Azhaga Saravana Babu, P., Babuskin S., Sivarajan, M., Sukumar, M. (2015). Modeling the kinetics of antioxidant extraction from origanum vulgare and Brassica nigra. Chemical Engineering Communications, 202(12), 1577-1585.

https://doi.org/10.1080/00986445.2014.957757

Mohammed, L.S., Mohammed, S.H. (2000). Protective effect of black seed oil from Nigella sativa against murine cytomegalovirus infection. International Journal of Immunopharmacology, 22(2000), 729-740.

https://doi.org/10.1016/S0192-0561(00)00036-9

Park, J. H., Lee, Y., Kim, Y., Yoon, K. (2017). Antioxidant and antimicrobial activities of Quinoa (Chenopodium quinoa Willd.) Seeds cultivated in Korea. Preventive Nutrition and Food Science 22(3), 195-202.

Semerci, A.B., Tunç, K., Okur, İ. (2020). Antioxidant activity of the fruits of pyracantha coccinea using ethanolic extract method. Food and Health, 6(1), 35-40.

https://doi.org/10.3153/FH20005

Sıcak, Y., Erdoğan Eliuz, E.A. (2019). Chemical content and biological activity spectrum of Nigella sativa seed oil. KSÜ Tarım ve Doğa Dergisi, 22(6), 928-934.

https://doi.org/10.18016/ksutarimdoga.vi.537674

Tan, M., Yöndem, Z. (2013). İnsan ve hayvan beslenmesinde yeni bir bitki: Kinoa. Alinteri Dergisi, 62-66.

Tunç, K., Semerci, A.B., Inceçayır, D., Sağıroğlu, M. (2019). Antimicrobial activity of different flower extracts. Current Perspectives on Medicinal \& Aromatic Plants, 2(1), 53-58.

https://doi.org/10.38093/cupmap.585933 
Üstü, Y., Keskin, A. (2019). Keten tohumunun tıbbi kullanımı. Ankara Medical Dergisi, 19(3), 665-669.

https://doi.org/10.17098/amj.624535
Virenda, V., Shalini, T., Nirala, K., Chetan, N., Kalpagam, P. (2013). In vitro evaluation on antioxidant and antimicrobial activity of spice extracts of ginger, Turmeric and Garlic. Journal of Pharmacognosy and Phytochemistry, 2(3), 143-148. 